\title{
A EDUCAÇÃO PARA QUILOMBOLAS: EXPERIÊNCIAS DE SÃO MIGUEL DOS PRETOS EM RESTINGA SECA (RS) E DA COMUNIDADE KALUNGA DO ENGENHO II (GO)
}

\author{
Marilene Leal Paré \\ Luana Paré de Oliveira* \\ Alessandra D’Aqui Velloso ${ }^{* * * *}$
}

\begin{abstract}
Uma dor de angústia, de escravidão, e ela existe até hoje e só diminui quando a gente levanta a cabeça e, aí, eles vêem que a gente não se intimidou. Eu vejo essas crianças correndo no terreiro. Existem leis, mas a maioria desconhece as leis. Acho que as crianças, desde crianças, deviam ser sabatinadas: qual a lei que te protege, que te ampara? (Roberto Potássio Rosa, Comunidade de São Miguel dos Pretos - Anjos \& Silva, 2004).
\end{abstract}

\begin{abstract}
RESUMO: As comunidades quilombolas brasileiras foram reconhecidas pelo governo na publicação do Artigo 68, no ADCT, Constituição de 1988, que, ao garantir-lhes a posse de terra, evocou questōes socioeconômicas, espaciais, jurídicas e culturais, trazendo a representatividade dos quilombos à sociedade. Ao observar a escola em São Miguel dos Pretos/Restinga Seca (RS) e Engenho II, território Kalunga/Cavalcante (GO), se quer ver o processo de construção
\end{abstract}

* Mestre em Educação pela Pontifícia Universidade Católica do Rio Grande do Sul (PUC/Rs) e coordenadora do Programa de Educação Anti-Racista junto à Pró-Reitoria de Extensão da Universidade Federal do Rio Grande do Sul (UfRGS).E-mail: lealpare@gmail.com

** Mestre em Geografia pelo Instituto de Ciências Humanas da Universidade de Brasília (unB) e membro do Centro de Estudos do Instituto Pró-Fundação Leopold Sedar Senghor, em Porto Alegre (RS). E-mail: luanapare@terra.com.br

*** Historiadora e mestre em Geografia no Instituto de Ciências Humanas da Universidade de Brasília (UNB).E-mail: ale_velloso@hotmail.com 
A educação para quilombolas: experiências de São Miguel dos Pretos...

de conhecimento no quilombo. Há diferenças e semelhanças importantes na relação escola-espaço quilombola gaúcho e goiano, e, na análise, considere-se a relação da produção de conhecimento dentro e fora da instituição escolar. Torna-se importante um novo olhar sobre a inserção do povo negro no sistema escolar, seja como receptor do conhecimento institucionalizado, seja como produtor da construção desse conhecimento. A história do negro, colocada à margem do processo histórico do país, reduz a importância do afrodescendente no processo civilizatório brasileiro.

Palavras-chave: Quilombos. Educação. Território. Auto-estima. Identidade.

THE EDUCATIONAL SYSTEM IN BRAZIL'S QUILOMBOLA COMMUNITIES: EXPERIENCES IN SÃO MIGUEL DOS PRETOS AND KALUNGA COMMUNITIES

ABSTRACT: Brazilian quilombola - maroon remainders - communities received official recognition in the 1988 Constitution, article 68 , which guarantees them ownership over their land. It raised socio-economic, spatial, juridical, and cultural issues showing what quilombola communities represent in the current Brazilian society. Based on the observation of schools in two quilombola territories São Miguel dos Pretos and Kalunga, respectively in southern and middle west Brazil - and taking into consideration the regional differences and similarities, we analyze knowledge production in and out of the educational institution. A new perspective on the real insertion of Afro-Brazilian people into the formal educational system - either as students and receptors or as producers of institutionalized knowledge - is urgent, since the history of this people is set aside from Brazil's historical process, thus reducing their importance in the civilizatory process of the nation.

Key words: Maroon's remainders. Quilombo. Educational system. Territory. Self-esteem. Identity.

\section{Introdução}

diversidade populacional e cultural brasileira é uma característi-
ca conhecida e referenciada em todas as análises das ciências so-
ciais e estudos educacionais nos tempos modernos. Entretanto,
a percepção concreta desta diversidade no cotidiano populacional, por
meio de ações presentes no dia-a-dia dos grupos majoritários e
minoritários do Brasil, ainda é incipiente. A educação formal coloca-se
como um dos elementos mais importantes para que esta inclusão seja 
realmente efetiva, pois, apesar de não atingir toda a população do país, seus resultados têm reflexos no cotidiano e nos hábitos da população brasileira, de diversas formas e em diferentes esferas.

Nesse sentido, destaca-se aqui a emergência das comunidades remanescentes de quilombos. Reconhecidas oficialmente pelo Estado brasileiro em 1988, principalmente com a afirmação de seus direitos territoriais por meio do Artigo 68 do Ato das Disposiçôes Constitucionais Transitórias da Constituição (ADCT), ${ }^{1}$ as comunidades quilombolas despertaram uma série de questôes socioeconômicas, espaciais, jurídicas e culturais que passaram a fazer parte da discussão sobre o que representam os quilombos contemporâneos na atualidade e sobre a sua efetiva inserção cidadã. Entretanto, para que essa inserção se realize, não basta que a sociedade obtenha o conhecimento sobre estes grupos, mas também que a população quilombola se veja dentro da sociedade atual, que o conhecimento ocidentalizado, eurocêntrico, presente nas escolas formais abra um espaço significativo para a vivência e educação destas comunidades. A obrigatoriedade do ensino da história e cultura africana e afro-brasileira nas escolas do país abre um precedente importante para que o aprendizado quilombola, bem como os modos de fazer e viver dos quilombos contemporâneos, seja considerado um saber essencial para a formação de uma nova estrutura de educação no Brasil, fundamental para que o país se reconheça como afrodescendente em sua formação humana e cultural.

No Brasil, segundo o Censo Escolar de 2004, existem 49.722 estudantes matriculados em 374 escolas localizadas em áreas de remanescentes de quilombos, sendo que $62 \%$ das matrículas estão concentradas na região Nordeste. $\mathrm{O}$ MEC vem construindo e equipando escolas em áreas rurais dos remanescentes de quilombos, através do Fundo de Fortalecimento da Escola (FUNDESCOLA), para que estados e municípios levem o ensino a estas populaçóes com uma metodologia que deverá seguir o princípio de ensino da Escola Ativa. O projeto arquitetônico elaborado pelo FUNDESCOLA oferece salas planejadas que obedecem aos padróes mínimos de funcionamento, prevendo também a construção da "Casa do Professor”, pois estão em áreas de difícil acesso aos professores; a contratação dos mesmos é garantida pelos municípios.

As experiências que aqui vão relatadas sobre os quilombos de São Miguel dos Pretos, no Rio Grande do Sul, e da Comunidade Kalunga de Engenho II, em Goiás, certamente nos levarão a refletir melhor sobre 
A educação para quilombolas: experiências de São Miguel dos Pretos...

o fazer pedagógico junto à população afrodescendente brasileira e não só a quilombola. Faz-se mister a conclusão efetiva da questão racial nos currículos escolares, reconhecendo a identidade étnica dos alunos negros e a valorização de suas potencialidades, a partir da ancestralidade africana. A escola é um espaço privilegiado de construção de conhecimento e a sociedade brasileira possui uma dívida com relação à reconstrução da identidade e auto-estima da população afrodescendente.

\section{O aprendizado quilombola e o ensino formal: o caso de São Miguel dos Pretos}

O Rio Grande do Sul é o estado brasileiro com maiores referências européias em sua formação, devido aos processos migratórios de alemães e italianos para lá no século XIX. Além disso, é sabido que o estado teve uma inserção tardia dentro do sistema escravagista colonial, devido a disputas históricas entre portugueses e espanhóis pela região e ao pouco interesse econômico inicial em relação ao território, já que as demandas coloniais se voltaram primeiramente para o Nordeste e Centro-Oeste do país. Contudo, a chamada Província de São Pedro deve muito da sua construção social ao trabalho escravo, além de ter contado com um contingente populacional africano significativo durante boa parte de sua história. No início do século XIX, algumas regiōes do Rio Grande do Sul destacavam-se pela significativa concentração de negros, dentre elas Triunfo, Viamão, Pelotas, Piratini, Santo Amaro (atual General Câmara), Porto Alegre, Conceição do Arroio (Osório), Cachoeira e Rio Pardo, e, por ser freqüente o número de negros superar o de brancos nessas regióes, estas áreas eram a fonte de muita apreensão dos senhores portugueses, devido ao expressivo número de escravos e conseqüente possibilidade de fugas e rebeliōes.

A existência de quilombos no Rio Grande do Sul era, até recentemente, ignorada pela historiografia. No entanto, há registros do século XVIII que citam fugas de escravos e nomeação de capitães-domato para capturar escravos aquilombados nos arredores das regióes mais produtivas do estado. Atualmente, o Rio Grande do Sul apresenta diversas comunidades remanescentes de quilombos, que hoje se encontram numa situação de expropriação de suas terras e de difícil sobrevivência. Resultantes de diversas formas de apropriação e ocupação territorial, as comunidades gaúchas são pequenas, mas numerosas, 
sendo registradas cerca de 90 comunidades quilombolas (Anjos, 2005), e ocupam diferentes áreas do estado rio-grandense. Cercados espacialmente por comunidades de origem alemã e italiana, carecendo de infra-estrutura adequada, os quilombos gaúchos são locais de resistência negra significativos numa região onde a população afrodescendente é notadamente minoria (cerca de $15 \%$ da população do estado) e busca sua visibilidade numa cultura local altamente europeizada.

Dentre essas comunidades, está o quilombo remanescente de São Miguel dos Pretos, situado na zona rural do município de Restinga Seca, centro do estado do Rio Grande do Sul, a $56 \mathrm{~km}$ de Santa Maria e a $277 \mathrm{~km}$ da capital, Porto Alegre. Santa Maria, por sua vez, está a $287 \mathrm{~km}$ da capital. Esta comunidade quilombola localiza-se às margens da rodovia RS-149, tem 90 hectares e abrange cerca de 160 famílias. Segundo o Laudo Territorial e Antropológico da comunidade (Anjos et al., 2002), São Miguel foi fundada por Geraldo Martins Carvalho, nascido escravo em 1838 na sesmaria da família Martins Pinto, grandes fazendeiros da região, e por Ismael Cavalheiro, escravo da família Carvalho Bernardes, também com significativo prestígio e terras na área. O território onde hoje está São Miguel foi ocupado por Geraldo Carvalho, em meados de 1850, e adquirido por ele e Ismael em 1892, estando localizado na faixa de terra entre os antigos limites das sesmarias Carvalho Bernardes e Martins Pinto. Geraldo e Ismael estabeleceram ali suas famílias e chamaram outros escravos libertos para lá permanecerem (Anjos \& Silva, 2004). Desde então, o povoado, formado basicamente por parentes, permanece no local.

A população de São Miguel tem sua subsistência na agricultura tradicional e nas plantações de fumo e de milho para venda, além de trabalharem nas fazendas vizinhas e na cidade, em atividades da indústria moveleira, serviços domésticos, comércio e indústria calçadista, em franco desenvolvimento na região. A agricultura na comunidade é praticada com o uso de adubo orgânico, obtido dos próprios animais. A infraestrutura, bastante precária, constitui-se de uma igreja, uma escola de ensino fundamental (até $8^{a}$ série), uma linha de ônibus e um centro comunitário, onde ocorrem todas as reuniōes da comunidade e funciona um pequeno posto de saúde. Boa parte da população é idosa e muitos jovens da comunidade trabalham em núcleos urbanos próximos (Restinga Seca, Agudo, Santa Maria). 
A educação para quilombolas: experiências de São Miguel dos Pretos...

A comunidade de São Miguel apresenta formas de organização do trabalho e sociabilidade que podem ser inseridas dentro do modo de vida camponês. Segundo Sérgio Schneider (2000), no sistema camponês as estruturas de sociabilidade estão calcadas nos laços familiares e de parentesco, nos grupos de vizinhança e na coletividade local. A produção tem por base a propriedade da terra, a produção de subsistência e trocas econômicas locais. Em São Miguel, as relações de descendência, vizinhança e os vínculos de parentesco são fundamentais para a identidade individual e identificação locacional dos moradores do quilombo. Esses elementos constitutivos do espaço são evidenciados na divisão do território da comunidade, a partir das heranças, assinalando a unicidade familiar aliada à percepção de pertencimento a troncos da família específicos, o que determina também seu sistema de trocas e relações com base em grupos de vizinhança. Este modo de fazer e viver norteia os processos de formação dos jovens, baseados no sistema de solidariedade ${ }^{2}$ e no aprendizado cotidiano através da experiência dos mais velhos.

A transmissão do conhecimento vivido pelos moradores mais antigos do quilombo tem na organização espacial de São Miguel um dos fatores importantes para sua perpetuação. Na cultura africana tradicional, todos os elementos da vida estão interligados. A religião, a política, a família, o território, a moradia somente têm sua função plenamente cumprida se estão intrinsecamente relacionados, e sua existência formal e estrutural está profundamente conectada com a estrutura dos demais itens da vida. Sendo assim, a tradição oral de transmissão do conhecimento, típica das sociedades africanas, só tem sentido com a proximidade do interlocutor, já que, para o africano, a comunicação tem que ser viva, dinâmica, e essa energia viva não é transmitida por meio das letras (Nascimento, 2002). A família, por sua vez, tem nas tradições de linhagem e parentesco um componente importante de estruturação familiar, de transmissão de conhecimento para as gerações seguintes. Isso cria a necessidade de proximidade das famílias, com a construção das casas dos filhos casados em torno das moradias dos mais velhos, pais e avós, o que estabelece, por si só, a manutenção da tradição, o aprendizado dos mais novos pela experiência dos mais velhos e as relações de vizinhança. Sendo assim, o princípio organizacional do espaço quilombola, ao constituir na atualidade um local de resistência e da vivência dos africanos que aqui chegaram, cumpre um papel fundamental na manutenção das formas de produção social, da cosmovisão 
africana e na sobrevivência desta população como comunidade negra constituída, com consciência de grupo e de origem comum.

Esta ocupação territorial pelas famílias obedece a um sistema de relaçôes em que a casa principal do grupo é a residência dos pais, que tem ligações diretas com a residência dos filhos; além destas, há uma terceira esfera de relações com as áreas de plantio e criação, com cada unidade de moradia tendo suas próprias hortas e pomares, embora de usufruto de todos os membros do núcleo familiar, obedecendo a um sistema de organização encontrado também em regiões de GuinéBissau, Angola e Moçambique até os dias atuais. ${ }^{3}$ As relações sociais assim determinadas levam a uma autonomia das famílias agrupadas, com suas áreas de criação e plantio para subsistência contidas na área familiar. Ao mesmo tempo, identifica-se o planejamento conjunto dos elementos de infra-estrutura da comunidade, como fontes de água, as antigas matas e áreas de pesca, fontes de alimento e manutenção do quilombo, em um sistema de autonomia e interdependência.

O aprendizado com os mais velhos se dá inclusive no processo de edificação da comunidade, com o aprendizado de ofícios diversos, transmitidos pelos mais velhos aos mais novos. O fato das casas dos filhos serem construídas em torno das casas dos pais facilita o processo de construção das moradias pelos homens do grupo familiar, trazendo a circularidade dos processos relacionais e educacionais (parentesco, vizinhança, aprendizado). A construção do quilombo de São Miguel, tanto no nível cultural quanto no relacional e territorial, está definida no seu espaço real, isto é, nas áreas históricas de apropriação do quilombo, trazidas como referenciais de ocupação, defesa, manutenção do grupo e estratégias de estruturação social diferenciada. A população identifica todo um espaço de vivência ancestral que permitiu a percepção do quilombo como o vemos hoje, e que faz parte das referências tradicionais e espaciais dos quilombolas, de acordo com as bases históricas de construção do território.

A formação social de São Miguel mostra-se, assim, rica em saber tradicional, em elementos de construção sócio-cultural significativos e adaptados ao meio, como todos os quilombos brasileiros, que procuraram aliar sua estrutura espacial e econômica e suas formas de vida social, constituídas a partir de modelos tradicionais africanos, à nova realidade da América (Nascimento, 2002). Entretanto, questiona-se aqui se este saber está inserido no processo educacional local. 
A educação para quilombolas: experiências de São Miguel dos Pretos...

Na década de 1950, os quilombolas desenvolveram uma estratégia de busca de acesso à educação formal, com imensa dificuldade, devido à localização de escolas em regiōes de imigrantes europeus, onde o negro não tinha inserção. Após levantamento do número de crianças sem escola no quilombo, a prefeitura viu-se obrigada a construí-la. A escola deu um novo sentido de comunidade ao grupo. Esta instituição é a Escola Municipal Manoel Albino Carvalho, construída pela prefeitura em substituição à escola original, que possuía apenas duas salas feitas de madeira. Estas salas são referidas pela população como a escola antiga, na qual lecionou uma professora negra, lembrada pela comunidade, que foi transferida mais tarde. Atualmente, a escola Manoel Albino é apresentada como um marco importante da comunidade, uma conquista, pois tem o nome de um dos patriarcas de São Miguel (Manoel Albino era filho de Geraldo Carvalho) e conta com instalações adequadas para o ensino. Os quilombolas assinalam com orgulho que todas as crianças estão na escola, que tem de $1^{\text {a }}$ a $8^{\text {a }}$ série. Entretanto, após este período, as crianças têm que se deslocar para Restinga Seca se desejarem continuar com os estudos. Há uma divergência de opiniões a esse respeito, sendo que muitas vezes os pais acham os filhos pequenos demais para irem para a "cidade". Em 2003 (época da pesquisa de campo), a comunidade pleiteava um ônibus escolar que levasse as crianças à escola pública de Restinga Seca para cursarem o $2^{\circ}$ grau.

O ensino formal é significativamente valorizado pela comunidade, além do local da escola, pela referência simbólica do nome e das possibilidades cidadãs que oferece. Entretanto, apesar de citada com freqüência pelo grupo, verifica-se certa distância entre o ambiente escolar e a vivência da comunidade. O plano curricular é semelhante aos do sistema municipal público em geral e os professores são designados pela prefeitura de Restinga Seca, sendo em sua totalidade pertencentes às áreas de colonização italiana das redondezas. Sendo assim, a escola constitui uma espécie de "ilha" importante no interior da comunidade, trazendo as referências formais consideradas essenciais pela população quilombola, mas com pouca ligação com o entorno imediato.

Uma busca pela conexão quilombo-escola ocorreu na década de 1990, com um trabalho sobre a dança afro junto à comunidade, que acabou sendo introduzido na escola. Este projeto, que permanece até hoje, apesar do grupo que trouxe o trabalho já não estar mais presente, é citado com freqüência pelos quilombolas, principalmente as crianças, 
como um fator importante e agregador de referências africanas e afrobrasileiras. Entretanto, apesar do trabalho ter se iniciado junto à comunidade de São Miguel e ter sido incluído na escola posteriormente, esta acabou por apropriar-se por completo do projeto, sendo o único lugar onde a dança afro é ensinada. Dessa forma, somente as crianças que estão na escola podem participar do grupo de dança, e os alunos que se formam são automaticamente excluídos devido ao término do ensino, mesmo desejando permanecer. Essa prática criou conflitos dentro da comunidade, uma vez que as crianças estabeleceram laços de pertencimento cultural a partir da dança, e sua saída da escola significa a perda de um elemento essencial de agregação e conhecimento cultural comunal. Este processo resultou no estabelecimento de um grupo externo, não conectado à escola. $\mathrm{O}$ seu surgimento gerou uma tensão sensível nas conversas da comunidade, criando algumas facções a favor e outras contra o novo grupo e gerando discussóes a respeito de qual deles realmente representaria a comunidade de São Miguel. Todavia, independente da discussão sobre a validade da cisão e multiplicação dos grupos de dança, identifica-se aqui uma tensão social gerada por uma apropriação de um processo cultural, originado na comunidade, pela escola municipal, que mantém um caráter diferenciado enquanto instituição simbólica eminentemente distante do cotidiano quilombola.

\begin{abstract}
A auto-estima como instrumento para a qualidade do ensino em comunidades remanescentes de quilombo: o caso da escola do Engenho II - Kalunga
\end{abstract}

Em 1997 chegou ao Ministério da Educação uma carta de um pai kalunga, morador de um remanescente de quilombo no norte de Goiás. Ele pedia que fosse construída uma escola em sua comunidade para que seus filhos não estivessem fadados a ler e escrever como ele. A auxiliar técnica Maria Auxiliadora Lopes iniciou o trabalho e hoje cuida especificamente da educação quilombola. Sabe-se que a maioria dos adultos é analfabeta e que, assim como as crianças e adolescentes em idade escolar, eles necessitam de um programa educacional que contemple sua história e sua cultura. (Gentile \& Bencini, 2003).

O território Kalunga está situado na região nordeste do estado de Goiás, compreendendo três municípios: Cavalcante, Monte Alegre 
A educação para quilombolas: experiências de São Miguel dos Pretos...

e Teresina, numa área total de 237 mil hectares. No período do Brasil colonial, sobretudo a partir do final do século XVII, a principal atividade produtiva desta região era a mineração, que caracterizou a relação de trabalho entre senhores e escravos. Sabe-se das diferentes formas e estratégias de resistência à escravidão elaborada pela população negra no período colonial, de acordo com cada contexto social específico. Nesta região, muitos negros escravizados conseguiram comprar sua alforria, adquirir terras e comercializar sua produção com as regiōes Norte e Nordeste do Brasil, especialmente com os estados do Pará e da Bahia.

A comunidade do Engenho il é uma das comunidades que fazem parte do território Kalunga, cujo tombamento como sitio histórico e cultural data do ano de 1991. Apesar desta e de outras conquistas, o principal elemento de reivindicação dos kalungas ainda não foi conquistado: a titulação de todo o seu território. No caso da comunidade do Engenho II, no mapeamento do território histórico-cultural realizado no ano de $2005,{ }^{4}$ foi identificado que esta se concentra em uma parte bastante reduzida do território, tendo acesso restrito às áreas de plantio, tradicionalmente definidas pela comunidade, cuja propriedade há muitos anos é de fazendeiros.

A relação entre quilombolas e fazendeiros é, na maioria das vezes, de conflito. Alguns fazendeiros adquiriram o título de suas terras por meio de grilagem, outros compraram de membros da comunidade, em um processo realizado de forma questionável, já que alguns dos que venderam suas áreas não possuíam documentação de propriedade; além disso, identificou-se também a sobreposição de domínios em algumas áreas. Sendo assim, a disputa pelo território faz parte do cotidiano da comunidade.

Um dos elementos que caracteriza o conflito entre quilombolas e fazendeiros é o acesso às áreas de roçado. Para que os membros da comunidade do Engenho II possam fazer suas roças, necessitam de pedir permissão aos fazendeiros, que autorizam a produção mediante pagamento de $20 \%$ da colheita. As principais culturas são arroz, feijão, milho, abóbora e mandioca e todo o cultivo é destinado à subsistência. Apenas a mandioca é destinada à comercialização. Sua farinha, bastante conhecida na região pela sua qualidade, é vendida nas cidades próximas. O gado é criado solto, mas apenas por algumas famílias que 
têm melhores condiçôes financeiras. Há criações de porco e galinha que ficam soltos, próximos às casas.

Segundo levantamento realizado pelo CIGA/UNB (2005), no estado de Goiás foram identificadas 27 comunidades remanescentes de quilombo, localizadas em 21 municípios; entretanto, como várias outras no restante do Brasil, poucas possuem a certificação da Fundação Cultural Palmares e apenas uma das comunidades do território Kalunga, próxima a Teresina, possui a titulação de suas áreas.

A primeira escola da comunidade do Engenho II funcionava na casa do Sr. Leopoldo (Seu Lió), onde sua filha, Joselina Francisco Maia, dava aulas às crianças da comunidade. Devido a conflitos pela posse da terra, esta casa já não existe mais, pois estava localizada em uma área que foi comprada por um fazendeiro. Segundo relato do Sr. Lió, este conflito ocorreu no início da década de 1980.

Em 1985 foi construída uma escola, na área onde hoje a comunidade está concentrada, batizada com o nome da sua primeira professora. A escola oferece às crianças e adolescentes da comunidade o ensino infantil e parte do ensino fundamental - pré-primário à sexta série e há alguns anos tem oferecido também, aos finais de semana, ensino aos jovens e adultos.

A escola Joselina Francisco Maia conta com 6 (seis) professores, dos quais 2 (dois) são homens e 4 (quatro) mulheres. Todas as mulheres são da comunidade e os homens vêm de outras áreas da região e não são quilombolas. A qualificação dos professores é muito baixa, apenas um deles cursa nível superior em Pedagogia, o único professor branco. Dois professores têm nível médio completo - sem nenhuma qualificação em licenciatura - e as demais fizeram um curso de formação intensiva para lecionarem na escola, há vários anos. Como todas as professoras mulheres são da comunidade, percebe-se certo conflito entre professores "de dentro" da comunidade e "os de fora" da comunidade.

Nas atividades desenvolvidas, durante o trabalho de campo, com os estudantes e professores da escola, foi possível perceber diferentes elementos a serem enfrentados para alcançar o ensino de qualidade. Entre eles, serão abordados, de acordo com a proposta deste artigo, dois elementos: a necessidade de relacionar o cotidiano das crianças e adolescentes, associado aos saberes da terra, com o conteúdo curricular proposto; e a importância em valorizar a auto-estima de professores e 
A educação para quilombolas: experiências de São Miguel dos Pretos...

alunos da escola, associada à necessidade de ampliar a oferta do ensino fundamental e médio na comunidade.

O saber tradicionalmente construído e o saber oferecido pela escola formal: um diálogo necessário

A questão do diálogo entre diferentes saberes é uma necessidade identificada em várias escolas situadas no meio rural. $\mathrm{Na}$ comunidade quilombola do Engenho II, verificou-se que existe a consciência dos familiares e das crianças e adolescentes quanto à importância do ensino oferecido pela escola formal, sobretudo na construção da autonomia do indivíduo na sociedade, o que significa reconhecer a capacidade destas pessoas de tomarem decisôes conscientes em todos os campos de sua vida e, sobretudo, nas relações estabelecidas com as pessoas de fora da comunidade. Entretanto, da associação entre o que se aprende na escola e a sua aplicação no cotidiano dos quilombolas pouco se pode aferir. Os estudantes não conseguem associar um aprendizado ao outro devido, é claro, à dissociação entre os saberes aprendidos na comunidade - ligado ao trato com a terra, ao significado simbólico do território associado à ancestralidade e à identidade étnico-racial, bem como aos rituais de celebração da colheita, como a festa de Nossa Senhora das Neves - e os saberes oferecidos nos conteúdos curriculares formais.

Apesar da publicação do livro Uma história do povo Kalunga, em 2001, significar um grande avanço para a implementação de um processo de ensino aprendizagem contextualizado e para a vida, foi verificada a dificuldade dos professores na utilização do livro, associando-o ao conteúdo curricular formal. Os professores percebem a necessidade de associar os diferentes saberes para, assim, buscarem melhorar o interesse dos estudantes com relação ao que a escola oferece. Porém, devido à baixa qualificação e à falta da formação continuada, estes professores acabam por trabalhar na escola apenas o que os livros didáticos oferecem.

Ainda durante o trabalho de campo, foi realizada uma atividade lúdico-pedagógica com os estudantes da escola Joselina Francisco Maia, atividade que teve como objetivo identificar os principais elementos que definem a relação deles com o território do Engenho II. O resultado desta atividade revelou que a relação dos estudantes com o espaço 
do Engenho II é bastante profunda: é neste lugar eles se sentem seguros e têm o domínio do espaço e das relaçôes estabelecidas.

Deve-se ressaltar que, assim como muitas outras comunidades remanescentes de quilombo, a comunidade do Engenho II é formada por pessoas que têm a mesma descendência. Outro aspecto identificado foi que muitos alunos e alunas possuem o sobrenome da mãe no final dos seus nomes, diferentemente do que ocorre geralmente nos registros civis no Brasil, em que o sobrenome do pai é que tem mais força e será passado aos seus filhos.

Sendo assim, para que a escola consiga cumprir seu papel como espaço de construção do conhecimento consciente e coletivo, sendo, portanto, um espaço apropriado por todos os membros da comunidade do Engenho II, é imprescindível que os professores passem por cursos de formação para poderem, assim, construir a conexão entre os diferentes saberes, além da aplicação em sala de aula dos temas transversais. Este processo continuado de formação dos professores certamente contribuirá para a contextualização do conteúdo curricular formal: língua portuguesa, matemática, ciências, educação física etc., de acordo com a realidade da comunidade remanescente de quilombo Kalunga - Engenho II.

Somente por esse caminho é que haverá de fato uma aprendizagem contextualizada e para a vida, considerando a sabedoria dos ancestrais desses estudantes aliada aos conteúdos curriculares. Muito se tem avançado neste sentido no Brasil, especialmente com a inclusão do artigo 26 na Lei de Diretrizes e Bases da Educação, que trata da obrigatoriedade do ensino da temática da história e cultura afro-brasileiras nos currículos do ensino fundamental e médio. Contudo, avanços como estes são apenas parte de um amplo processo, de longa duração na história, de luta para a inclusão social da população negra no Brasil.

Auto-estima e qualidade de ensino nas comunidades remanescentes de quilombo

A auto-estima da população negra é um dos elementos fundamentais a serem considerados para que estes sujeitos sociais construam solidamente sua autonomia. Durante o período dos trabalhos desenvolvidos na escola Joselina Francisco Maia, a questão da baixa 
A educação para quilombolas: experiências de São Miguel dos Pretos...

auto-estima revelou-se de maneira muito forte entre estudantes, especialmente os adolescentes, e professores.

A baixa auto-estima dos professores leva a um processo complexo e muito negativo, com influência em todos os campos da vida. No ambiente escolar, este aspecto se revela, entre outras formas, pela falta de estímulo de estudantes e professores no processo de ensino-aprendizagem. Conforme já enunciado, os professores do Engenho II não contam com um processo de formação continuada que os oriente em sua ação pedagógica, sobretudo para lidar com a temática das relações étnico-raciais.

Para que esses professores possam tratar de assuntos referentes às relações étnico-raciais, é necessário que eles trabalhem a sua auto-estima, identificando os seus próprios valores, o que sentem ao viverem em uma sociedade racista e como elaboram este sentimento para enfrentar a discriminação. Somente por meio da reflexão e da tomada de consciência deste problema é que a ação destes professores irá contribuir para a construção da auto-estima dos estudantes quilombolas.

Outro aspecto associado à questão do racismo é o fato de que a escola do Engenho II oferece o ensino apenas até a $6^{\text {a }}$ série. Sendo assim, para continuar os estudos, as crianças e adolescentes têm que sair da comunidade, dirigindo-se, na maioria das vezes, à cidade de Cavalcante.

É claro que não são todos os estudantes que têm condições financeiras para morar na cidade. Os poucos que podem enfrentam diversos problemas: adaptação ao meio urbano; distância dos familiares e o racismo, além da responsabilidade de ser a esperança da família na conquista de uma vida melhor. Estas questôes são complexas e difíceis de serem enfrentadas por qualquer pessoa adulta, e para estas crianças e adolescentes torna-se ainda mais difícil.

Nesse processo de ruptura com os principais elementos que constituem a identidade desses estudantes, a saber: família, comunidade e modo de vida tradicional, eles se deparam com um mundo novo e organizado por elementos diferentes dos seus.

Em entrevista realizada com uma das professoras da comunidade, que tem dezessete anos de idade, ela revelou que o principal problema enfrentado pelos estudantes quilombolas em Cavalcante é a discriminação racial. Ela conta que, na escola de Cavalcante, sempre 
sofreu discriminação por ser Kalunga e por ser negra. Além disso, um dos aspectos evidenciados por ela é a solidão que, segundo seu depoimento, leva muitas meninas a engravidarem precocemente.

De acordo com a professora, para minimizar esses problemas é necessário abordá-los em sala de aula para que os estudantes consigam enfrentar melhor a discriminação e os desafios existentes fora do território Kalunga.

Situações como esta ocorrem com jovens que vivem no meio rural em diferentes regiôes do Brasil, mas a questão da discriminação racial é um elemento vivenciado mais intensamente pela população negra e também pelos quilombolas e, portanto, deve ser abordado nas escolas, contribuindo assim para a construção de sujeitos sociais críticos e conscientes de sua importância na sociedade.

\section{Considerações finais}

Neste país continental, remanescentes de africanos de norte e sul, embora em regiōes tão diversas, apresentam as mesmas dificuldades, necessidades e anseios, reivindicando seus direitos de cidadania brasileira. Isso nos reporta às responsabilidades dos gestores nas políticas públicas para essas populações, principalmente as ligadas à educação, que se caracteriza como a grande reivindicação observada.

Entre 1998 e 2001, primeiros anos de trabalho do MEC, uma equipe visitou diversas comunidades negras para fazer o levantamento de suas necessidade. Essa iniciativa deu origem ao Projeto Vida e História das Comunidades Remanescentes de Quilombos no Brasil. O primeiro projeto que virou realidade foi justamente o dos kalungas. Pesquisadores na UNB pesquisaram a história e o modo de vida desse grupo e produziram um livro, um caderno de atividades, um encarte para o professor e uma exposição itinerante de fotografia. (Gentile \& Bencini, 2003)

Essa iniciativa da UNB poderia ter servido como exemplo às demais universidades, já que o Plano Plurianual 2004-2007 previa recursos para iniciativas semelhantes em outras regióes do país.

O MEC, para assegurar uma educação de qualidade aos alunos quilombolas, destinou recursos por meio da Secretaria de Educação Continuada, Alfabetização e Diversidade (SECAD) para financiar as seguintes ações no ensino fundamental: 
A educação para quilombolas: experiências de São Miguel dos Pretos...

- formação continuada para professores que atuam em comunidades remanescentes de quilombo;

- construção e ampliação de escolas;

- aquisição de material para-didático;

- elaboração de material didático.

Acreditamos ser necessária uma fiscalização efetiva junto às Secretarias de Educação quanto à utilização dessa verba no seu objetivo primeiro, que vem a ser as comunidades quilombolas. Da mesma forma, se a perspectiva é de respeito às raízes étnicas:

a) Os projetos arquitetônicos das escolas respeitam a forma de saber das comunidades quanto à utilização de espaços?

b) Todas as escolas para remanescentes de quilombos estão em efetivo funcionamento e com professores habilitados?

c) Até que ponto os projetos educacionais subsidiados pelo MEC estão atingindo os estudantes provenientes dos quilombos e que estão em outras escolas públicas (municipais, estaduais)?

A educação no Brasil é um fato complexo de ser discutido, em diferentes âmbitos. A questão da diversidade real e efetiva nos enfoques educacionais e curriculares necessita, assim, de uma ampla discussão em diferentes esferas, e nas comunidades quilombolas isso não é diferente. Em São Miguel, a necessidade do ensino formal identificada pela população, que buscou essa inserção no processo educacional dos seus filhos, procurando uma maior inclusão social, tem o contraponto da exclusão do entorno imediato, com o estabelecimento de espaços claramente divididos entre o cotidiano e o saber da comunidade, essencial para a formação dos mais novos e para o sentido de comunidade tradicional, e a escola como símbolo do ensino formal, do "externo" que traz a inclusão cidadã. Contudo, esta divisão tão clara impede o diálogo entre esses dois ambientes sociais, cujos conhecimentos podem ser complementares, ampliando a formação e as possibilidades, tanto da escola quanto da comunidade, com o compartilhamento e o aprendizado conectivo, ampliando sobremaneira a visão de mundo não só dos alunos, mas também da escola pluricultural que temos hoje. 
A escola brasileira precisa estudar melhor os esquemas de pensamento do seu alunado e, sobretudo, as dimensōes da expressão afrocultural dos afrodescendentes, a fim de que se possa, realmente, discutir a existência de um ensino democrático, inclusivo e emancipatório no Brasil.

\section{Recebido em outubro de 2006 e aprovado em março de 2007.}

\section{Notas}

1. "Aos remanescentes das comunidades dos quilombos que estejam ocupando suas terras é reconhecida a propriedade definitiva, devendo o Estado emitir-lhe os títulos respectivos" (Artigo 68 do ADCT da Constituição da República Federativa do Brasil, 1988).

2. Solidariedade, aqui, está associada ao sistema de rede solidária, baseado em uma estrutura de gerenciamento do território da comunidade por núcleos autônomos e associados, garantindo a manutenção das fontes familiares e comunais de sobrevivência, consoante Oliveira (2005).

3. Baseado em estudos de Weimer (s/d).

4. O mapeamento do território do Engenho II foi realizado para a dissertação de mestrado, em andamento, cujo tema é o processo histórico espacial da comunidade do Engenho II Kalunga. O processo de construção do mapa foi coletivo e contou com a participação de vários membros da comunidade, especialmente do Sr. Jorge, que foi o guia.

\section{Referências bibliográficas}

ALMEIDA, A.W.B. Viagem a Alcântara. In: SOCIEDADE MARANHENSE DE DIREITOS HUMANOS. A história ameaçada: a luta das comunidades tradicionais contra a política colonialista da base espacial de Alcântara. São Luís: SMDH, 2001.

ANJOS, J.C. et al. Laudo antropológico do Quilombo de São Miguel. Porto Alegre: [s.n.], 2002.

ANJOS, J.C.; SILVA, S.B. (Org.). São Miguel e Rincão dos Martimianos: ancestralidade negra e direitos territoriais. Porto Alegre: UfRGS, 2004.

ANJOS, R.S.A. Coleção África - Brasil: cartografia para o ensinoaprendizagem. Brasília, DF: Mapas Ed. \& Consultoria, 2000. v.1.

ANJOS, R.S.A. Territórios das comunidades quilombolas no Brasil: segunda configuração espacial. Brasília, DF: Mapas Ed. \& Consultoria, 2005. 
A educação para quilombolas: experiências de São Miguel dos Pretos...

DORIA, S.Z.; OLIVEIRA JUNIOR, A.N. Laudos periciais antropológicos e a particularidade das terras ocupadas por comunidades remanescentes de quilombos. Textos \& Debates, Florianópolis, p. 8-21, 1996.

GENTILE, P.; BENCINI, R. Remanescentes de quilombos: descobrir a própria história. Nova Escola on-line, ed. 165, set. 2003. Disponível em: http://revistaescola.abril.com.br/edicoes/indice_anteriores_2007.shtml. Acesso em: 30 maio 2006.

LEITE, I.B. Quilombos e quilombolas: cidadania ou folclorização? Horizontes Antropológicos, Porto Alegre, v. 5, n. 10, p. 123-150, maio 1999.

NASCIMENTO, A. O quilombismo. Brasília, DF: Fundação Cultural Palmares, 2002.

NUNES, J.C.R. O direito constitucional de propriedade das comunidades remanescentes de quilombos. Textos \& Debates, Florianópolis, n. 8,2000 .

OLIVEIRA, L.P. O espaço de São Miguel dos Pretos: arquitetura e territorialidade africanas no Sul do Brasil. 2005. Dissertação (Mestrado em Geografia) - Instituto de Ciências Humanas, Universidade de Brasília, Brasília.

OLIVEIRA, R. Uma história do povo kalunga. Brasília, DF: Secretaria de Educação Fundamental, 2001.

SCHNEIDER, S. Curso de capacitação para formadores em politicas públicas. Porto Alegre, 2000. (Notas de aula).

SEFFNER, F. (Org.). Presença negra no Rio Grande do Sul. Porto Alegre: UE, 1995. (Cadernos Ponto \& vírgula, 11).

WEIMER, G. O trabalho escravo no Rio Grande do Sul. Porto Alegre: Sagra; UFRGS, 1991.

WEIMER, G. Os aldeamentos africanos. Porto Alegre, [s.d.]. (mimeo.) 